\title{
Pathogenic Streptomyces spp. Abundance Affected by Potato Cultivars
}

\author{
Kamrun Nahar, Claudia Goyer, ${ }^{\dagger}$ Bernie J. Zebarth, David L. Burton, and Sean Whitney
}

First, second, third, and fifth authors: Fredericton Research and Development Centre, Agriculture and Agri-Food Canada, 850 Lincoln Road, Fredericton, NB, Canada; and fourth author: Department of Environmental Sciences, Dalhousie University, Agricultural Campus, P.O. Box 550, Truro, NS, Canada.

Accepted for publication 12 April 2018.

\begin{abstract}
Potato cultivars vary in their tolerance to common scab; however, how they affect common scab-causing Streptomyces spp. populations over time is poorly understood. This study investigated the effects of potato cultivar on pathogenic Streptomyces spp. abundance, measured using quantitative PCR, in three spatial locations in a common scab-infested field: (i) soil close to the plant (SCP); (ii) rhizosphere soil (RS); and (iii) geocaulosphere soil (GS). Two tolerant (Gold Rush, Hindenburg) and two susceptible cultivars (Green Mountain, Agria) were tested. The abundance of pathogenic Streptomyces spp. significantly increased in late August compared with other dates in RS of susceptible cultivars in both years. Abundance of pathogenic Streptomyces spp., when averaged

over locations and time, was significantly greater in susceptible cultivars compared with tolerant cultivars in 2014. Principal coordinates analysis showed that SCP and RS soil properties ( $\mathrm{pH}$, organic carbon, and nitrogen concentrations) explained 68 and $76 \%$ of total variation in Streptomyces spp. abundance among cultivars in 2013, respectively, suggesting that cultivars influenced common scab pathogen growth conditions. The results suggested that the genetic background of potato cultivars influenced the abundance of pathogenic Streptomyces spp., with five to six times more abundant Streptomyces spp. in RS of susceptible cultivars compared with tolerant cultivars, which would result in substantially more inoculum left in the field after harvest.
\end{abstract}

Potato (Solanum tuberosum L.) common scab is a bacterial disease caused by several species of Streptomyces. The pathogen infects actively growing potato tubers causing superficial, raised or pitted lesions on the surface of potato tubers (Loria et al. 1997). Common scab lesions reduce potato marketability in the table market, cause declassification of seed potato, and increase losses in the processing industry. No potato cultivars are completely resistant to the common scab pathogen; however, some cultivars are tolerant and thus disease severity remains low even under conducive conditions and high disease pressure.

Several Streptomyces spp. can induce common scab including $S$. scabies and S. europaeiscabiei, the two species that are more frequently found in North America (Wanner 2009). Although some pathogenic Streptomyces spp. produce other phytotoxins (Bignell et al. 2014), most pathogenic Streptomyces spp. inducing common scab symptom on potato tubers produced thaxtomins, a key pathogenicity factor of pathogenic Streptomyces causing common scab (Healy et al. 2000; King et al. 1989). The $t x t A, t x t B$, and $t x t C$ genes are involved in the biosynthesis of thaxtomins (Healy et al. 2000 , 2002) thus making these genes a useful target to quantify pathogenic Streptomyces in soil. Previous studies have determined the effect of soil properties (Sagova-Mareckova et al. 2017), or biocontrol agent (Arseneault et al. 2015; St-Onge et al. 2011) on the abundance of pathogenic Streptomyces spp.

Bactericides are ineffective or unavailable in controlling soilborne diseases caused by bacterial pathogens including common scab. Agricultural practices such as green manure and animal manure to control common scab were reported to be highly variable from year to year or site to site (Conn and Lazarovits 1998; Curless et al. 2012). A better understanding of the changes in abundance of pathogenic

${ }^{\dagger}$ Corresponding author: C. Goyer; E-mail: claudia.goyer@agr.gc.ca

Funding: This study was supported by the Agri-Innovation Program of Agriculture and Agri-Food Canada.

(C) Her Majesty the Queen in Right of Canada, as represented by the Minister of Agriculture and Agri-Food Canada, 2018.
Streptomyces spp., and the factors influencing their growth, would be useful in developing better management practices to control common scab.

Plant species is an important factor influencing the selection of microbial communities and pathogens (Garbeva et al. 2004). Furthermore, several studies showed that plant cultivar, within a plant species, influences the size of the soilborne plant pathogen population (An et al. 2011; Raaijmakers et al. 2009; Wu et al. 2008). In several pathosystems, the composition of root exudates from disease susceptible and resistant plants was different, and modulated soilborne pathogens either by promoting or inhibiting their growth (An et al. 2011; Li et al. 2013; Piattoni et al. 2014; Sun et al. 2013; Wu et al. 2008). For example, there was a difference in the root exudates from wilt resistant and susceptible peanut cultivars in terms of sugars contents, total amino acid and total phenolic acids. Additionally, root exudates from the susceptible cultivar had a greater effect on germination, sporulation, and mycelial growth of soilborne pathogens, F. oxysporum and Fusarium solani compared with the resistant cultivars (Li et al. 2013). Root exudate composition is known to differ among potato cultivars (Balendres et al. 2016; Gschwendtner et al. 2011; Hannula et al. 2010; Rasche et al. 2006). Sources of nutrients supporting pathogens and microbial communities in the geocaulosphere are unclear; however, cell decay, exudates, and volatile compounds from potato tubers, which are underground stems, were reported (Dijst 1990; Dobson et al. 2008). Two studies have evaluated the effect of potato cultivars on the abundance of pathogenic Streptomyces spp. (Keinath and Loria 1989). Keinath and Loria (1989) showed a greater abundance of S. scabies on the tuber surfaces of susceptible potato cultivars compared with tolerant cultivars; however, this study used a culture-dependent approach to quantify the pathogen population. $S$. turgidiscabies was measured in the rhizosphere and tuber surface of common scab susceptible and tolerant potato cultivars; however, the pathogen was inoculated in soil thus it was not indigenous to the field (Kobayashi et al. 2015) and this species is rarely found in North America. Furthermore, these studies did not investigate how soil physicochemical properties modulated pathogenic Streptomyces growth. 
The objective of this study was to investigate the changes in the abundance of pathogenic Streptomyces spp. in soils close to the plant roots, in the rhizosphere, and in the geocaulosphere (tuber surface) over the potato growing season. Possible relationships between pathogenic Streptomyces spp. abundance and soil environmental parameters were explored. The hypothesis of the study was that significant differences in the pathogenic Streptomyces spp. abundance among potato cultivars and over the growing season would be observed in the rhizosphere, and in the geocaulosphere.

\section{MATERIALS AND METHODS}

Experimental site and treatments. The experiment was conducted in an agricultural field (latitude $45^{\circ} 55^{\prime} 13.000^{\prime \prime} \mathrm{N}$, longitude $66^{\circ} 36^{\prime} 32.010^{\prime \prime} \mathrm{W}$, World Meteorological Organization ID: 71668) at the Fredericton Research and Development Centre of Agriculture and Agri-Food Canada (Fredericton, NB, Canada). The site has a maritime climate and humid soil moisture regimes. The experiments were conducted from May to September in 2013 and 2014. The daily average air temperature during the May to September growing season was 16.1 and $16.3^{\circ} \mathrm{C}$, and total precipitation was 710 and $549 \mathrm{~mm}$, in 2013 and 2014, respectively (http://climate. weather.gc.ca/, station: Fredericton CDA CS). Soils at the experimental site belong to the Research Station soil association, which consists of coarse loamy morainal ablational till over coarse loamy morainal lodgement till, and are classified in the Canadian Soil Classification System as Orthic Humo-Ferric Podzols (Rees and Fahmy, 1984). The soil is a sandy loam (58.7\% sand, $24.9 \%$ silt, and $16.4 \%$ clay) with an average $\mathrm{pH}$ of 5.8. The total nitrogen $(\mathrm{N})$ and total carbon $(\mathrm{C})$ were 0.19 and $2.1 \%$, respectively.

A field naturally infested with common scab was used. In order to compare the effect of potato cultivars on abundance of pathogenic Streptomyces spp., four potato cultivars were tested including two common scab tolerant cultivars (Goldrush and Hindenburg) and two susceptible cultivars (Green Mountain and Agria). The experimental site used a randomized complete block design with four (2013) or six (2014) replicates. Each plot consisted of one row of 20 potato plants of a given cultivar that were separated by three seed pieces of a red variety Chieftain to avoid mixing between cultivars. Granular fertilizer (formulation 17-17-17 of N-P-K) was banded at planting at the rate of $1,134 \mathrm{~kg} \mathrm{ha}^{-1}$. Standard commercial practices were used for control of diseases, insects, and weeds (Bernard et al. 1993). No irrigation was applied as is common in this region.

Soil sampling and soil analyte measurements. Soil samples were collected on seven dates: before planting (late May), at plant emergence (early July), at early and late tuberization period (mid and late July), at tuber bulking stage (late August), at harvest (late September), and after harvest (October). Bulk soil samples were collected from each block before crop planting and after crop harvest when no crop was present. Each bulk soil sample was a composite of six soil cores from 0 to $15 \mathrm{~cm}$ depth taken using a soil sampler in randomly selected locations within the plot. The soil was thoroughly mixed and a subsample was transferred to sterile $15 \mathrm{ml}$ centrifuge tubes. For all other sampling dates (early July, mid-July, late July, late August, and late September), soil samples were collected from three spatial locations: (i) soil close to the plant (i.e., sampled from the hill adjacent to the plant; SCP); (ii) rhizosphere soil (i.e., the soil in close contact with roots; RS); and (iii) geocaulosphere soil (i.e., the soil in close contact with potato tubers; GS). Destructive sampling was done using one randomly selected plant per plot on each sampling date. Plants and soil surrounding the roots were gently removed using a shovel. The SCP was obtained by shaking the soil surrounding the roots in a large plastic bag, mixing and then collecting a subsample in a sterile $15 \mathrm{ml}$ tube. After shaking off and discarding any loose soil from the roots, the rhizosphere (RS) and geocaulosphere soil (GS) were sampled by collecting the first few millimeters of adhering soil from the roots and tubers. Soil samples were immediately frozen in liquid nitrogen on site and subsequently stored at $-80^{\circ} \mathrm{C}$ until processed.
Soil (5 g) was extracted with $0.5 \mathrm{M} \mathrm{K}_{2} \mathrm{SO}_{4}$ (1:2, soil/solution ratio), filtered, and stored at $-20^{\circ} \mathrm{C}$ pending analysis. Blank solution samples were also filtered to estimate contamination. Segmented flow analysis (Technicon Industrial Systems, Tarrytown, NY) was used for the colorimetric determination of extractable organic carbon (EOC), $\mathrm{NH}_{4}{ }^{+} \mathrm{N}$ and $\mathrm{NO}_{3}{ }^{-} \mathrm{N}$ concentrations in the extracts (Miller et al. 2008). Soil pH was measured using a $\mathrm{pH}$ meter after shaking soil/water (1:1) solution. Soil particle size distribution (texture) was assessed by pipette method (Kroetsch and Wang 2008). In 2013, all these soil properties were measured for both SCP and RS soil; however, in 2014, the analysis was done for SCP only because there was insufficient RS soil for analyses. Soil temperature and volumetric water content (VWC) were monitored from May to October using a Decagon EM50 data logger equipped with 5TE sensors. A data logger was installed in the field and two sensors were installed at $15 \mathrm{~cm}$ depth.

Disease severity and incidence assessment. Twenty randomly selected tubers from each plot were used to evaluate disease severity. The tubers were washed and then disease severity was evaluated visually on each individual tuber. Disease severity was measured by determining the percentage of the tuber surface covered by lesions (i.e., a score between 0 to $100 \%$ ) by comparing with a disease scoring key to help evaluate the extent of the symptoms and to ensure that the evaluation was consistent. Disease incidence was calculated by determining the proportion of tubers with greater than $5 \%$ common scab lesion coverage, which is the threshold for tuber marketability used by the Canadian potato industry.

Primer and probe design for quantitative PCR. Absolute quantification of populations of pathogenic Streptomyces spp. abundance were performed using TaqMan-based qPCR targeting $t x t C$ gene, a cytochrome P450 monooxygenase involved in the biosynthesis of thaxtomins. The $t x t C$ sequences (FJ007580 to FJ007629, AF393159) were retrieved from the National Center for Biotechnology Information database. Nucleotide sequences of a given gene were aligned using the CLUSTALW function in the BioEdit sequence alignment editor 7.0.4.1 software (Hall 2001). PrimerQuest tool (Integrated DNA technologies design software) was used to design primers and TaqMan probes in conserved regions of the txtC gene sequences. The $5^{\prime}$ extremities of the probes were labeled with the reporter dye 6-carboxy fluorescein, whereas their 3' extremities were labeled with the minor groove binder nonfluorescent quencher. The sequences of primers and probes as well as PCR product lengths are presented in Table 1. Primers and TaqMan probes were purchased from Integrated DNA Technologies.

Quantification of pathogenic Streptomyces spp. using txtC gene using qPCR. Soil samples were freeze-dried and total genomic DNA was extracted from soil $(0.25 \mathrm{~g}$ dry weight $)$ with a PowerMag Soil DNA Isolation Kit (MOBIO Laboratories, Inc., Carlsbad, CA) using Thermo Scientific KingFisher Flex magnetic particle processor according to manufacturer protocol. DNA was quantified with a Picogreen assay (Invitrogen, Burlington, Ontario) using a 96-well plate fluorometer (Fluoroskan Ascent; Thermo Fisher Scientific, Waltham, MA). The qPCR reactions were conducted using the TaqMan Fast advanced Master Mix (Thermo Fisher scientific, Toronto, Canada) and a Step One Plus Real-Time

TABLE 1. Nucleotide sequences of the primer and TaqMan probe used in this study

\begin{tabular}{lllc}
\hline $\begin{array}{l}\text { Target } \\
\text { gene }\end{array}$ & Name & \multicolumn{1}{c}{ Sequence $\left(5^{\prime} \rightarrow 3^{\prime}\right)$} & $\begin{array}{c}\text { Product } \\
\text { size } \\
(\mathrm{bp})\end{array}$ \\
\hline & $\begin{array}{l}\text { txtC-F } \\
\text { txtC-R } \\
\text { txtC-Probe }\end{array}$ & $\begin{array}{l}\text { TGTTCGTGGACGACGGAGAACTT } \\
\text { TACGACACGACGGCCAGCACCAT }\end{array}$ & 72 \\
& AGTGCATAACTCACCAAGGACAGCGA & \\
\hline
\end{tabular}


PCR System (Applied Biosystems, Streetsville, ON, Canada). Each $10-\mu \mathrm{l}$ reaction contained primers and probe $(200 \mathrm{nM})$ and $2 \mu \mathrm{l}$ of 1 : 10 diluted DNA ( 15 to $70 \mathrm{ng} / \mu \mathrm{l}$ ). Three qPCR replicates were used per sample and three no-template controls were included during each qPCR run. The thermal cycling conditions were as follows: $2 \mathrm{~min}$ at $50^{\circ} \mathrm{C}, 20 \mathrm{~s}$ at $95^{\circ} \mathrm{C}$, followed by 40 cycles of $1 \mathrm{~s}$ at $95^{\circ} \mathrm{C}$ and $20 \mathrm{~s}$ at $60^{\circ} \mathrm{C}$. Standard curves were generated using five replicates of serial dilutions of a known number of plasmids containing a 2,265bp fragment of the $t x t C$ gene of pathogenic Streptomyces spp. The standard curve descriptors (slopes, intercept [Y], efficiency [E], and coefficient of determination $\left[R^{2}\right]$ ) were as follows: slope $=-3.1$ to $-3.3, \mathrm{E}=100.0$ to $111.7 \%, R^{2}=0.98$ to $0.99, \mathrm{Y}=35.8$ to 40.6 .

Statistical analysis. Statistical analyses were conducted using SigmaPlot-13 software (Systat software Inc., Chicago, IL). Analyses of variance (ANOVA) were performed for disease severity, incidence and abundance of pathogenic Streptomyces spp. using potato cultivars and sampling time as fixed factors. Treatment means and their interactions were compared by Fisher's least significant difference test. Pearson correlation coefficients $(r)$ were used to determine possible relationships between the abundance of pathogenic Streptomyces spp. and the disease severity. The differences and correlation coefficients presented were significant at $P \leq 0.05$.

Possible influence of potato cultivars on soil properties (soil $\mathrm{pH}, \mathrm{NH}_{4}{ }^{+} \mathrm{N}, \mathrm{NO}_{3}{ }^{-} \mathrm{N}$, and EOC) was evaluated in SCP and RS using principal coordinates analysis (PCoA) and significance was determined using permutational multivariate analysis of variance (PERMANOVA). The analyses were done on normalized data based on Euclidean distance. Distance-based linear modeling (DistLM) was conducted to model the percentage of overall variation in pathogenic Streptomyces spp. abundance accounted for by each soil property (soil $\mathrm{pH}, \mathrm{NH}_{4}{ }_{4} \mathrm{~N}, \mathrm{NO}_{3} \mathrm{~N}, \mathrm{EOC}$, soil temperature, volumetric water content, soil clay, and sand) (Anderson 2001). Step-wise regression was used as selection procedure and $R$-squared criterion $\left(R^{2}\right)$ as the selection criterion. A distance-based
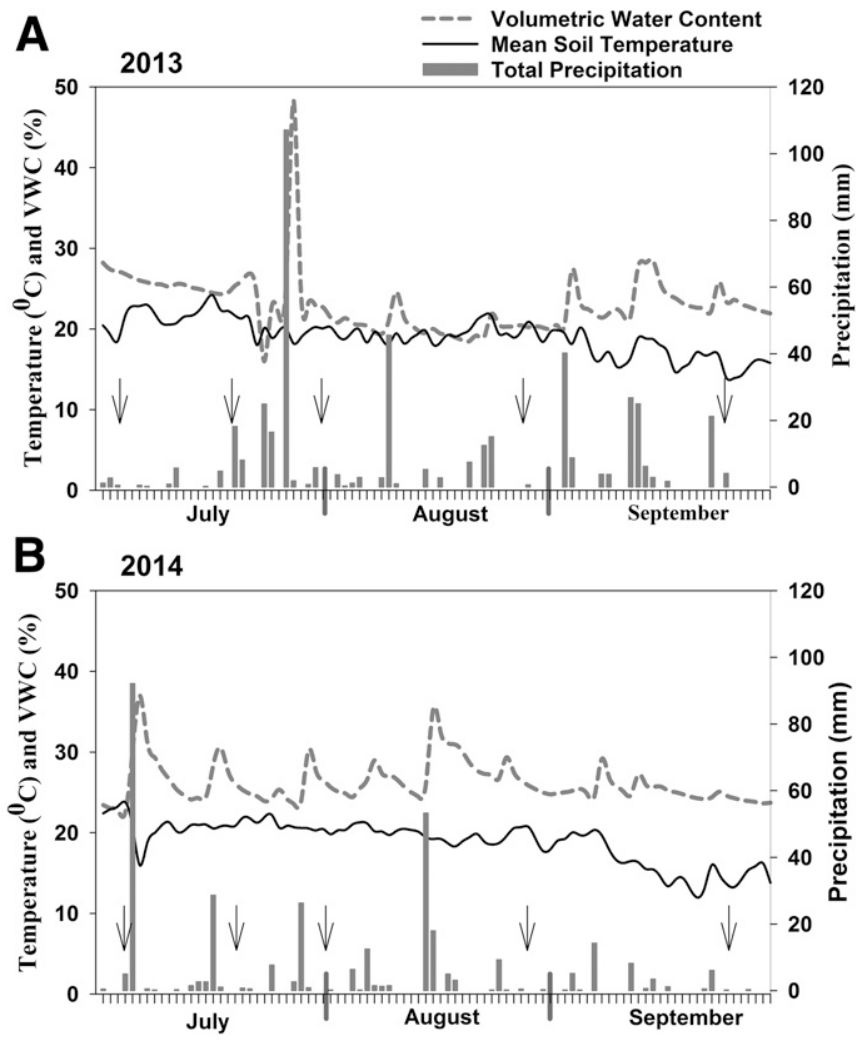

Fig. 1. Daily precipitation, mean soil temperature and soil volumetric water content in A, 2013 and B, 2014 during potato growth. Arrows indicate sampling dates. redundancy analysis (dbRDA) biplot was generated to visualize the relative contributions of each of the predictor variables on the pathogenic Streptomyces spp. abundance at individual time point (Legendre and Anderson 1999). The similarity (resemblance) of each pair of samples in terms of pathogenic Streptomyces spp. abundance and soil properties was calculated using the Bray-Curtis similarity and Euclidean distance, respectively. The PCoA, DistLM, and dbRDA analyses were preformed using Primer-6 (Clarke and Gorley 2006).

\section{RESULTS}

Environmental conditions. Soil temperatures and volumetric water content (VWC) were measured throughout the potato growing season at $15 \mathrm{~cm}$ depths using two sensors. The results are presented in Figure 1 for both summers, along with daily precipitation (from Environment Canada, climate station: Fredericton CDA CS) over the sampling period. There was an apparent difference in VWC and precipitation between two summers. The monthly average VWC in 2013 was 25.6, 20.2, and 23.1\% in July, August and September, respectively, whereas, monthly average VWC in 2014 was 26.3, 27.3, and $25.1 \%$ in July, August, and September, respectively. The total precipitation for this time period was 446 and $329 \mathrm{~mm}$ in 2013 and 2014, respectively. There was no apparent difference in the average soil temperatures in July, August, and September between the two summers.

Severity and incidence of potato common scab. Common scab severity and incidence of four potato cultivars were evaluated at harvest in 2013 and 2014. Significant differences in the severity of common scab between susceptible and tolerant cultivars were observed in both years (Fig. 2). Average values of 13 and 20\% in lesion coverage were observed in susceptible cultivars (Agria and Green Mountain) compared with 1 and $2 \%$ in lesion coverage in tolerant cultivars (Goldrush and Hindenburg) in 2013 and 2014, respectively (Fig. 2A and B). Susceptible cultivars, Agria and Green Mountain, had between 82 to $88 \%$ and 58 to $85 \%$ of the tubers with more than 5\% lesion coverage in 2013 and 2014, respectively (Fig. $2 \mathrm{C}$ and $\mathrm{D})$. In contrast, average common scab incidence for tolerant cultivars, Hindenburg and Goldrush, was less than $1 \%$ in both years (Fig. 2C and D). There were no significant differences in common scab severity and incidence between tolerant cultivars in either year (Fig. 2). Common scab severity and incidence were significantly greater in cultivar Agria compared with Green Mountain in 2013, but not in 2014.

Abundance of pathogenic Streptomyces spp. The abundance of pathogenic Streptomyces spp. in bulk soil was measured in May (before planting) and in October (after harvest) for both years. The $t x t C$ gene copies $\mathrm{g}^{-1}$ of dry soil were $3.1 \times 10^{5}$ and $3.6 \times 10^{5}$ in May and October in 2013, while in 2014, txtC gene copies were $2.3 \times 10^{4}$ and $5.8 \times 10^{4}$, respectively.

Two approaches were used to observe differences in the dynamics of pathogenic Streptomyces spp. First, overall general trends were observed by averaging the data over time and over three spatial locations (SCP, RS, and GS). Second, more specific trends were observed by reporting on the cultivar-time interaction.

When averaged over SCP, RS, and GS and over time, the pathogenic Streptomyces spp. abundance was significantly different $(P \leq 0.001)$ among different cultivars (Fig. 3). Susceptible cultivars (Agria and Green Mountain) had 15- and 17-fold greater pathogenic Streptomyces spp. abundance in SCP, RS, and GS when averaged over time compared with tolerant cultivars (Hindenburg and Goldrush) for 2013 and 2014, respectively (Fig. 3). Pathogenic Streptomyces spp. abundance was significantly $(P \leq 0.001)$ greater in one of the susceptible cultivar Green Mountain compared with both tolerant cultivars Hindenburg and Goldrush for both years (Fig. 3A and B). Pathogenic Streptomyces spp. abundance was significantly $(P \leq 0.001)$ greater in Agria compared with both tolerant cultivars in 2014 (Fig. 3B) but only to Goldrush in 2013 (Fig. 3A). There was a significant 
difference $(P \leq 0.05)$ in the abundance of pathogenic Streptomyces spp. between the two susceptible cultivars, where Green Mountain had greater abundance compared with Agria (Fig. 3A and B) in 2013 and 2014. There was, however, no significant difference $(P \leq$ 0.05 ) in pathogenic Streptomyces spp. abundance between the two tolerant cultivars Hindenburg and Goldrush in either year (Fig. 3A and B).

In soil close to the plant ( $\mathrm{SCP}$ ), the abundance of pathogenic Streptomyces spp. changed significantly over time and among cultivars, and a significant cultivar-time interaction was observed, for both years (Fig. 4A and B). The txtC gene copy numbers were greater for cultivars Agria and Green Mountain in late August compared with other sampling times in 2013. In contrast, the pathogenic Streptomyces spp. abundance was greater at early tuberization stage (mid-July) in cultivar Hindenburg in 2013 compared with other sampling times, whereas there were no significant changes in abundance over time in the Goldrush cultivar. The abundance of pathogenic Streptomyces spp. was similar in SCP for all cultivars in 2014, except for Green Mountain (Fig. 4B). The abundance of pathogenic Streptomyces spp. in SCP of Green Mountain was greater in late August compared with other sampling times. In 2013 and 2014, there was also a significant $(P \leq 0.001)$ effect of cultivar on the abundance of pathogenic Streptomyces spp. in SCP when averaged over time (Fig. 4A and B). In both years, the abundance of pathogenic Streptomyces spp. averaged over time was significantly greater in cultivar Green Mountain compared with cultivars Hindenburg and Goldrush. Significantly greater pathogenic Streptomyces spp. abundance was observed in 2013 in SCP in susceptible cultivar Agria compared with cultivar Goldrush but not with Hindenburg, while in 2014 pathogenic Streptomyces spp. abundance was not significantly different in SCP among cultivars Agria, Hindenburg, and Goldrush.

In the $\mathrm{RS}$, there was a significant cultivar-time interaction on txtC gene copy numbers in both years (Fig. 4C and D). The abundance of pathogenic Streptomyces spp. in cultivar Green Mountain RS was consistently greater than cultivars Hindenburg and Goldrush rhizosphere in 2013 and 2014 (Fig. 4C and D). In contrast, pathogenic Streptomyces spp. abundance in Agria RS was significantly greater from tolerant cultivar Goldrush, but not from Hindenburg, in 2013, whereas the opposite was observed in 2014. There was a significant difference in the abundance of pathogenic Streptomyces spp. in RS over time in 2013 for all cultivars except Goldrush. Significantly greater abundance of pathogenic Streptomyces spp. in cultivars Green Mountain, Agria, and Hindenburg was observed in late August compared with other sampling times (Fig. 4C). In 2014, cultivars Agria and Green Mountain RS had greater abundance of pathogenic Streptomyces spp. in late August than in other sampling times, whereas abundance of did not differ significantly over time for cultivars Goldrush and Hindenburg (Fig. 4D).

In GS, there was a significant cultivar-sampling time interaction in 2013 in the abundance of pathogenic Streptomyces spp. (Fig. 4E). In 2013, the pathogenic Streptomyces spp. abundance in cultivars Agria and Green Mountain GS was significantly greater in late September compared with other sampling times, whereas there were no significant differences over time in cultivars Goldrush and Hindenburg. In contrast, the abundance of pathogenic Streptomyces spp. in GS was similar over time in all cultivars with the exception of Agria, where the pathogenic Streptomyces spp. abundance was significantly greater in late August compared with other sampling times. In 2013, the number of $t x t C$ gene copies per gram of soil in GS was similar in late July and late August when averaged over cultivars, while a significant increase was found in late September (Fig. 4E). In contrast, the abundance of $t x t C$ gene copies when averaged over cultivars did not change significantly over time in GS in 2014 (Fig. 4F). When averaged over time, Green Mountain had a significantly greater number of $t x t C$ gene copies in GS compared with other cultivars in both years. When averaged over
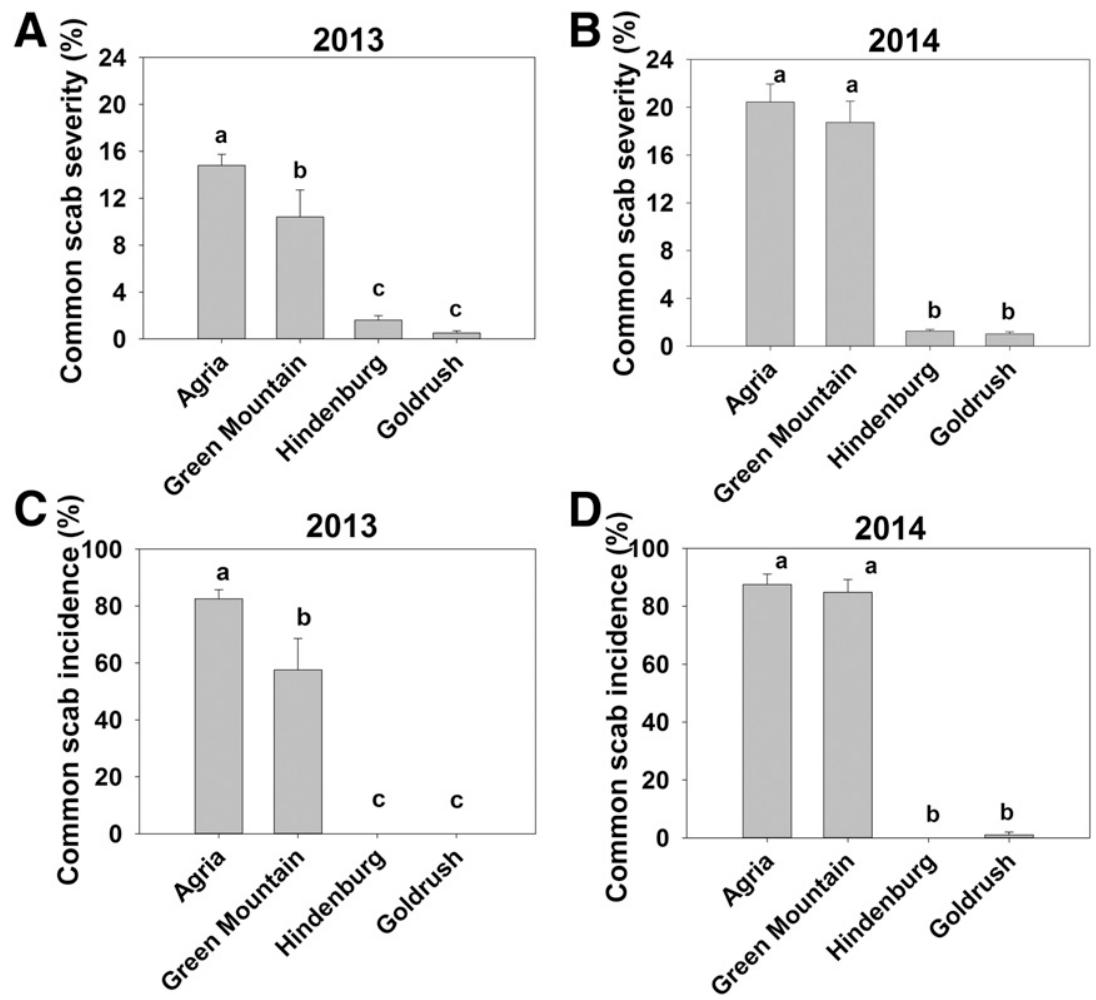

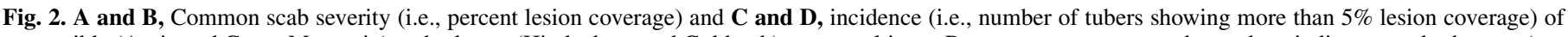

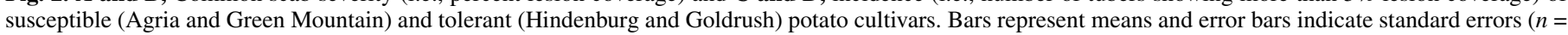

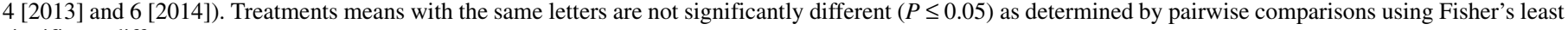
significant difference test. 
time, the number of $t x t C$ gene copies increased 15- and 17-fold in cultivar Green Mountain GS compared with cultivars Hindenburg and Goldrush in 2013 and 2014, respectively. There was significantly greater pathogenic Streptomyces spp. abundance observed in Agria GS when averaged over time compared with tolerant cultivars Hindenburg and Goldrush in 2013 and 2014 (Fig. 4E and F).

Relationships between abundance of pathogenic Streptomyces spp. and common scab severity. Possible relationships between abundance of pathogenic Streptomyces spp. (averaged over time) and common scab severity were explored in each location (i.e., SCP, RS, and GS). In 2013, there was a significant positive correlation between pathogenic Streptomyces spp. abundance in SCP and disease severity for Agria (Fig. 5A), but not in RS and GS. There were no significant correlations between the abundance of pathogenic Streptomyces spp. and disease severity in any locations for other cultivars in 2013. In 2014, significant correlations between pathogenic Streptomyces spp. abundance in SCP and RS and disease severity of cultivar Green Mountain were observed (Fig. 5B). No significant correlation between abundance and severity in other cultivars for any of the location were observed in 2014.

Differences in soil properties between cultivars. Soil properties of SCP and RS may be influenced by the potato cultivar. To investigate this, principal coordinates analysis (PCoA) were performed to evaluate the importance of soil $\mathrm{pH}$, $\mathrm{NH}_{4}{ }^{+} \mathrm{N}, \mathrm{NO}_{3}{ }^{-} \mathrm{N}$, and EOC in explaining differences in soil properties among cultivars (Table 2; Fig. 6). The environmental variables (soil $\mathrm{pH}, \mathrm{NH}_{4}{ }^{+} \mathrm{N}, \mathrm{NO}_{3}{ }^{-} \mathrm{N}$, and EOC) explained 68 and $76 \%$ of the variation in soil properties among cultivars in SCP and RS in 2013, respectively (Table 2; Fig. 6A and B). In 2014, no significant differences in soil properties of SCP (soil properties not determined in $2014 \mathrm{RS}$ ) among the cultivars were observed (Table 2; Fig. 6C).

Factors influencing the pathogenic Streptomyces spp. abundance. Distanced-based redundancy analyses (dbRDA) were performed to evaluate the importance of soil properties (VWC, temperature, $\mathrm{pH}, \mathrm{NH}_{4}{ }^{+} \mathrm{N}, \mathrm{NO}_{3}{ }^{-} \mathrm{N}$, EOC soil clay, and sand) in explaining differences in pathogenic Streptomyces spp. abundance over time. In 2013, VWC and soil clay had a significant effect on abundance of pathogenic Streptomyces spp. over time in SCP. In contrast, soil temperature and $\mathrm{pH}$ had a significant effect on pathogenic Streptomyces abundance in SCP over time in 2014 (Table 3; Fig. 7A and C). In the case of RS in 2013, there was a significant correlation between the pathogenic Streptomyces spp. abundance and soil properties $\mathrm{VWC}$, soil clay, and $\mathrm{NH}_{4}{ }^{+} \mathrm{N}$ which explained $29.5,6.7$, and $3.6 \%$ of the total variation in the pathogenic Streptomyces spp., respectively (Table 3; Fig. 7B).

\section{DISCUSSION}

Disease severity and incidence. The overall common scab severity and incidence in all cultivars was about 1.5- and 1.2-fold lower in 2013 compared with 2014 , respectively. This was probably due to wet soil conditions during tuber initiation in 2013, which is the critical period for common scab infection, with $165 \mathrm{~mm}$ of rain in late July of 2013 compared with $39 \mathrm{~mm}$ in late July of 2014. Similarly, other studies have reported increased common scab severity increased in dry warm seasons (Haynes et al. 2010; Loria 2001; Powelson et al. 1993). In this study, significant differences in the severity and incidence of common scab between common scab susceptible (Agria and Green Mountain) and tolerant cultivars (Hindenburg and Goldrush) were observed for both years. Moreover, there was a significant difference in common scab severity and incidence between two susceptible cultivars, Agria and Green Mountain, in 2013 but not in 2014. Pathogenic Streptomyces spp. abundance, when averaged over time in the SCP, RS, and GS, was greater in Green Mountain than the abundance of Agria for both years. These results suggested that the difference in common scab severity between Agria and Green Mountain in 2013 was not due to a difference in the common scab pathogen abundance. Differences in host genetics between Green Mountain and Agria could explain why Agria was more susceptible to common scab compared with Green Mountain under the conditions encountered in 2013. It is possible that the more favorable condition in common scab development resulted in similar severity of the disease in Agria and Green Mountain in 2014, suggesting that cultivar genetics not pathogen levels control disease severity and incidence.

Differences in pathogenic Streptomyces spp. abundance between cultivars. Pathogenic Streptomyces spp. abundance was affected by potato cultivars when averaging the data over time and over three locations (SCP, RS, and GS). Susceptible cultivars (Agria and Green Mountain) had 15- and 17-fold greater pathogenic Streptomyces spp. abundance in SCP, RS, and GS when averaged over time compared with tolerant cultivars (Hindenburg and Goldrush) for 2013 and 2014, respectively. Furthermore, the abundance of pathogenic Streptomyces spp. was consistently greater in Green Mountain in SCP and RS compared with Hindenburg and Goldrush in both years when analyzed separately for each location. This indicates that the differences in genetic
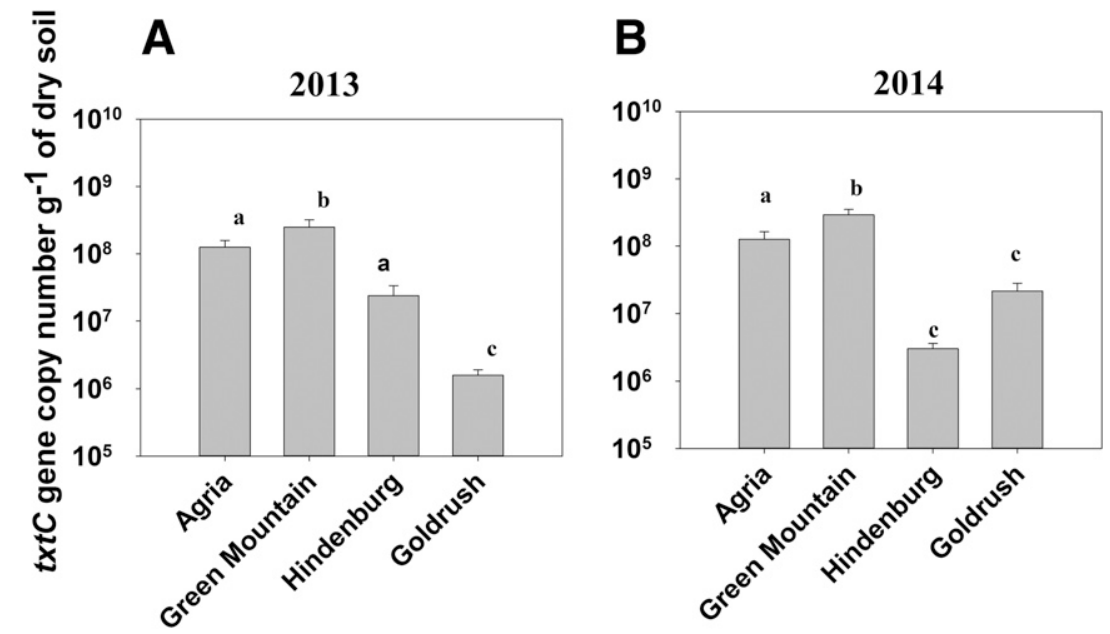

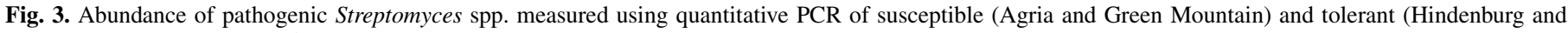

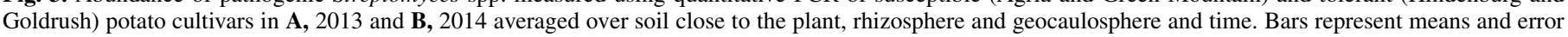

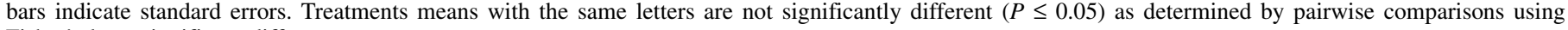
Fisher's least significant difference test. 

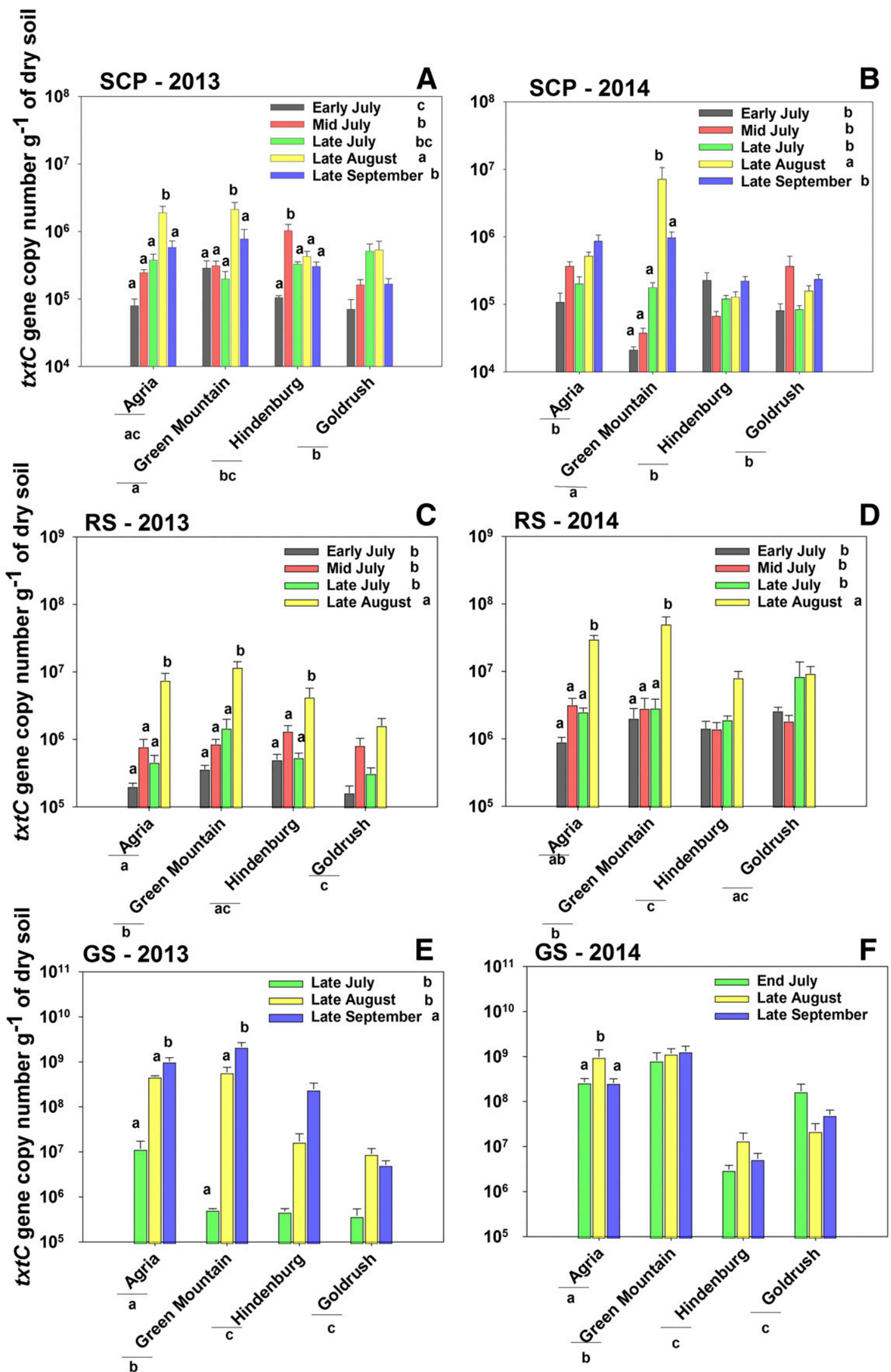

Fig. 4. Abundance of pathogenic Streptomyces spp. in $\mathbf{A}$ and B, soil close to the plant (SCP), $\mathbf{C}$ and D, rhizospheric soil (RS), and $\mathbf{E}$ and $\mathbf{F}$, geocaulosphere soil (GS) measured using quantitative PCR of susceptible (Agria and Green Mountain) and tolerant (Hindenburg and Goldrush) potato cultivars. Bars represent means and error bars indicate standard errors. Significant differences among means $(P \leq 0.05)$ are presented based on Fisher's least significant difference test using three approaches: (i) differences among time-cultivar interactions are indicated by letter over the bars in the graph, (ii) significant differences among cultivars are presented by letters under cultivar names along the x-axis, and (iii) significant differences over time are indicated by letters in the figure legend. Only significant results are presented. 
profiles among cultivars changed the abundance of pathogenic Streptomyces spp. This response may be due to differences in the quantity and composition root exudates among potato cultivars. This is consistent with the PCoA results showing that soil properties (i.e., soil $\mathrm{pH}, \mathrm{NH}_{4}{ }^{+} \mathrm{N}, \mathrm{NO}_{3}{ }^{-} \mathrm{N}$, and EOC) differed among cultivars in SCP and RS in 2013. In 2014, soil properties were not significantly different among cultivars perhaps due to differences in soil edaphic conditions. Previous studies reported that root exudation patterns differed among cultivars (Gschwendtner et al. 2010; Smalla et al. 2001; Soderberg et al. 2004). Pathogen growth differences among potato cultivars were previously reported

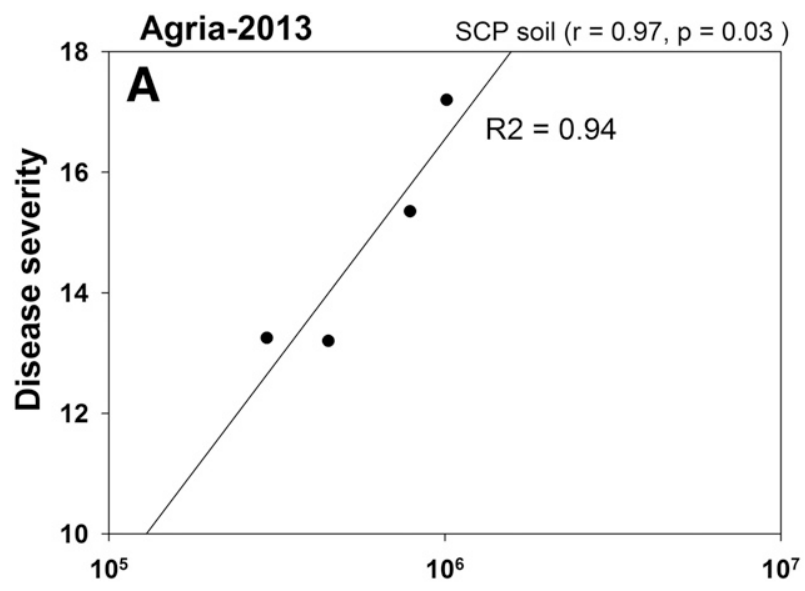

txtC gene copy number $\mathrm{g}^{-1}$ of dry soil

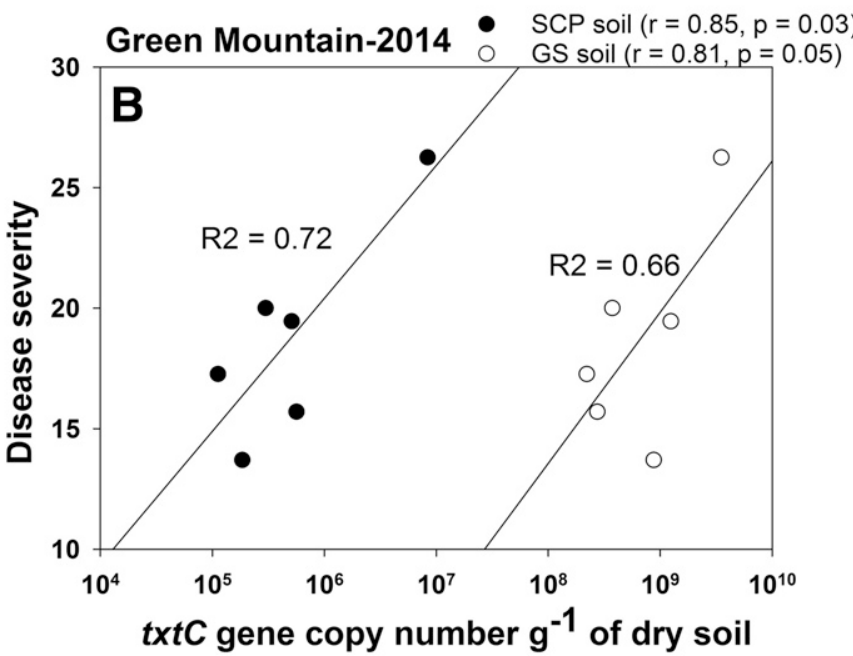

Fig. 5. Relationship between disease severity of common scab and A, pathogenic Streptomyces spp. abundance at harvest in soil close to the plant (SCP) for Agria and B, pathogenic Streptomyces spp. abundance in SCP and geocaulosphere soil (GS) for Green Mountain. Only significant relationships $(P \leq 0.05)$ are presented.

TABLE 2. Results of permutational multivariate analysis of variance testing for differences in soil properties among cultivars ${ }^{\mathrm{a}}$

\begin{tabular}{lccc}
\hline Soil samples & Degrees of freedom & Pseudo-F & $P$ value \\
\hline 2013 & 3 & 2.0 & $\mathbf{0 . 0 2 8}$ \\
SCP & 3 & 3.3 & $\mathbf{0 . 0 0 1}$ \\
RS & & & \\
2014 & 3 & 0.7 & 0.708 \\
SCP & NA & NA & NA \\
RS &
\end{tabular}

a SCP, soil close to the plant; RS, rhizosphere soil; and NA, not available. Significant $P$ values are indicated in bold.
(Hernandez Maldonado et al. 2013). For example, a twofold increase in pathogen Spongospora subterranea DNA in roots of powdery scab susceptible potato compared with the resistant cultivar was observed in a greenhouse trial (Hernandez Maldonado et al. 2013), which was attributed to greater concentrations of 24 lowmolecular weight organic compounds within potato root exudates of susceptible potato cultivars (Balendres et al. 2016).

It is possible that susceptibility to common scab may not be the only factor explaining differences in pathogenic Streptomyces spp.
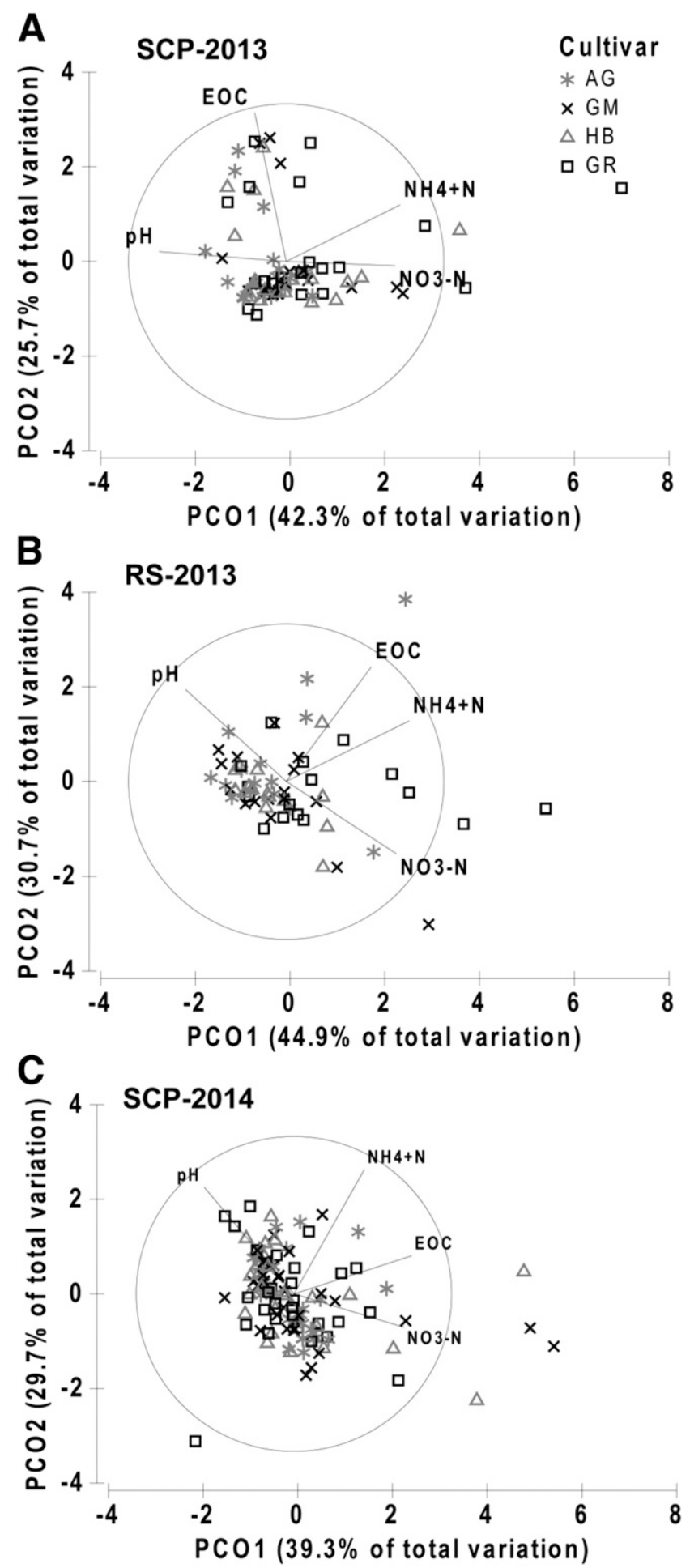

Fig. 6. Differences in soil properties (soil $\mathrm{pH}, \mathrm{NH}_{4}{ }^{+} \mathrm{N}, \mathrm{NO}_{3}{ }^{-} \mathrm{N}$, and EOC) among four cultivars in A, soil close to the plant (SCP) in 2013, B, rhizosphere soil (RS) in 2013, and C, SCP in 2014 using principal coordinates analysis (PCoA). AG, Agria; GM, Green Mountain; HB, Hindenburg; GR, Goldrush; and EOC, extractable organic carbon. 
abundance. In some studies, it was shown that pathogen populations may not differ between tolerant and susceptible cultivars. For example, study by Keinath and Loria 1989 reported no differences in the abundance of cultivable actinomycetes and S. scabies between RS of susceptible cultivar Chippewa compared with tolerant cultivar Superior. Similarly, in this study, in contrast to Green Mountain, pathogenic Streptomyces spp. abundance in SCP and RS of Agria was similar to Hindenburg in 2013 and to Goldrush in 2014. Other differences among cultivars may explain the differences in abundance of pathogenic Streptomyces spp. including maturity timing and allocation of carbon to starch. For example, differences in allocation of starch between cultivars was suggested to explain differences in relative abundances of Alpha- and Beta-Proteobacteria with an increase in the RS of cultivars with high starch content tubers compared with low starch content tubers (İnceoğlu et al. 2011). In this study, the cultivars were chosen to have similar maturity timing and ranged from mid to late maturity.

The rhizosphere forms a nutrient-rich niche for microorganisms as a result of exudation of compounds and as a result of that, it can be expected that the RS would influence growth of pathogenic Streptomyces spp. (Berg and Smalla 2009; Weller et al. 2002;). However, abundance of Streptomyces spp. among cultivars also differed in SCP, suggesting that the plants may have influenced soil beyond the RS. Similarly, a previous study reported a similar abundance of pathogenic Streptomyces spp. in soil from top and bottom of a pot compared with soil adhering to roots and tubers (Wang and Lazarovits 2005). In addition, the relative abundance of Actinobacteria was not different between bulk soil and rhizosphere soil at some potato growth stages (İnceoğlu et al. 2011), suggesting that the plant may have also influenced bulk soil. The effect of the plant on the SCP was small in magnitude and was not easily detected, therefore interpretation should be considered with caution.

Both susceptible cultivars had a significant increase in the number of $t x t C$ gene copies in GS compared with both tolerant cultivars in both years. This is probably due to the increased in growth of pathogenic Streptomyces spp. in the tuber tissues of susceptible tubers while on tolerant cultivars, the growth of pathogenic Streptomyces spp. would mostly be on the surface of the tubers where intense competition with other microbes would occur thus limiting growth of the pathogen. Similarly, Keinath and Loria (1989) showed that cultivable population of total actinomycetes and S. scabies were greater on the tuber surfaces of the susceptible cultivar Chippewa compared with tolerant cultivar Superior. Kobayashi et al. (2015) studied the effect of eight potato cultivars with different tolerance levels against common scab in artificially infested $S$. turgidiscabies field and found that $S$. turgidiscabies abundance in the tubers

TABLE 3. Factors explaining variability in pathogenic Streptomyces spp. abundance in soil close to the plant (SCP) and rhizosphere soil (RS) over time determined using a distance-based linear model ${ }^{\mathrm{a}}$

\begin{tabular}{lccc}
\hline Variable & Pseudo-F & $P$ value & \% Variation \\
\hline 2013 SCP $\left(R^{2}=0.18\right)$ & & & \\
VWC & 10.8 & $\mathbf{0 . 0 0 1}$ & 27.0 \\
Clay & 10.4 & $\mathbf{0 . 0 0 1}$ & 1.9 \\
2013 RS $\left(R^{2}=0.34\right)$ & & & \\
VWC & 10.3 & $\mathbf{0 . 0 0 1}$ & 29.5 \\
Clay & 8.3 & $\mathbf{0 . 0 0 1}$ & 6.7 \\
NH $_{4}^{+} \mathrm{N}$ & 5.2 & $\mathbf{0 . 0 0 9}$ & 3.6 \\
2014 SCP $\left(R^{2}=0.22\right)$ & & & 20.5 \\
Temperature & 18.1 & $\mathbf{0 . 0 0 1}$ & 1.4 \\
Soil pH & 5.0 & $\mathbf{0 . 0 0 9}$ & \\
2014 RS: NA & & & \\
\hline
\end{tabular}

a Variables are listed in order of contribution in explaining significant variation in pathogenic Streptomyces spp. abundance. The percent variation represents explained variation attributable to each variable added to the model. VWC, volumetric water content; and NA, not available. Significant $P$ values are indicated in bold. significantly decreased in tolerant cultivars compared with susceptible cultivars. Wanner (2007) showed that more pathogenic Streptomyces spp. isolates were obtained from scabby potato tubers of susceptible potato cultivars or breeding lines compared with a tolerant cultivar. Variability in the pathogenic Streptomyces spp. abundance between susceptible and tolerant cultivars GS may be due to differences in the tuber structure i.e., increase resistance in penetration by pathogens and/or to biochemical resistance to infection (Khatri et al. 2011). Khatri et al. (2011) showed that the common scab tolerant Russet Burbank had greater phellem suberization and thicker and more numerous cell layers in the phellem compared with the susceptible cultivar Desiree.
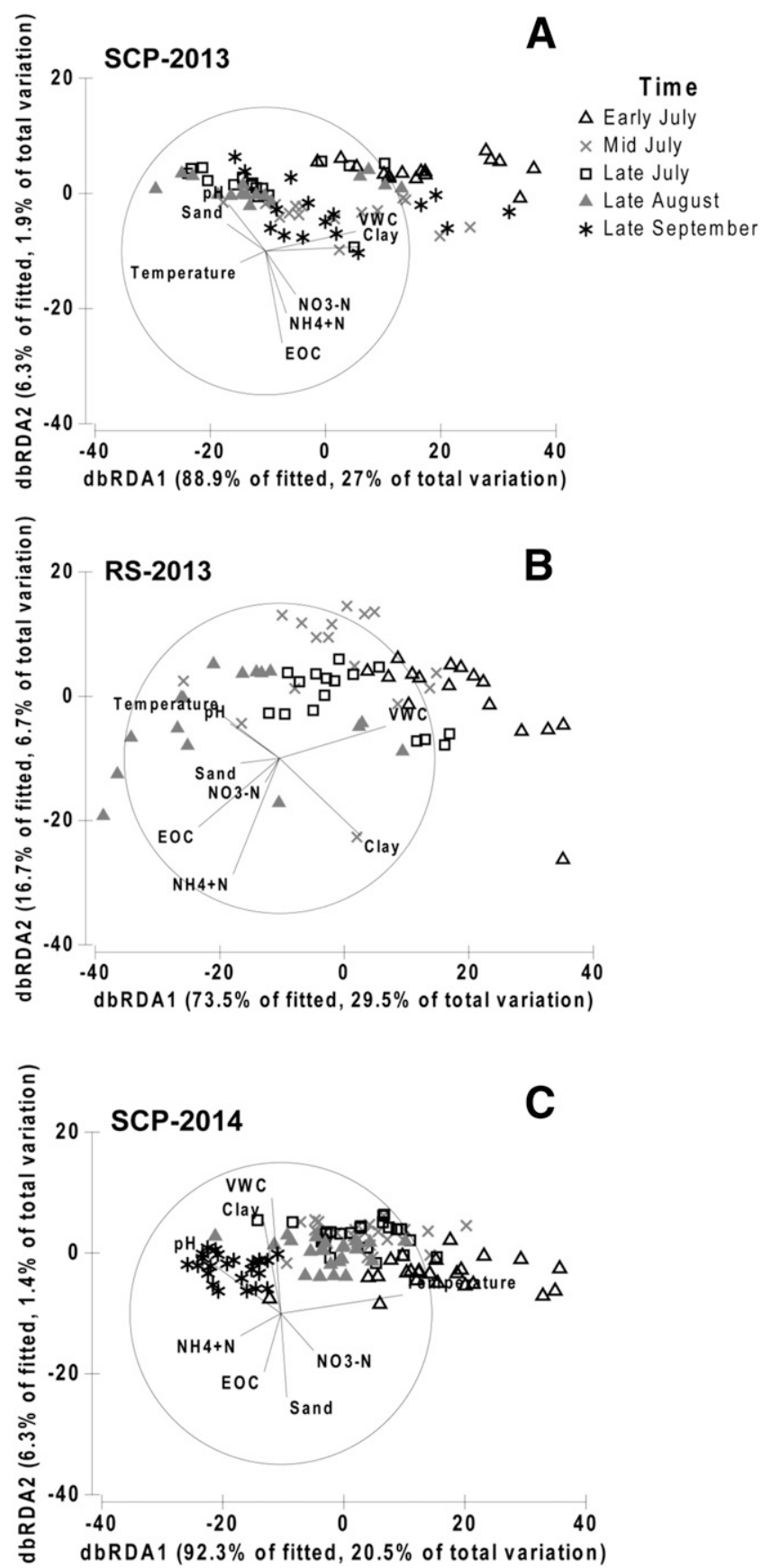

Fig. 7. Distance-based redundancy analysis (dbRDA) showing properties of $\mathbf{A}$, soil close to the plant (SCP) in 2013, B, rhizosphere soil (RS) in 2013, and $\mathbf{C}$, soil close to the plant (SCP) in 2014 and explaining the variability in pathogenic Streptomyces spp. abundance over time. Soil properties included soil volumetric water content (VWC), soil temperature, clay and sand, soil $\mathrm{pH}$, $\mathrm{NH}_{4}{ }^{+} \mathrm{N}, \mathrm{NO}_{3}{ }^{-} \mathrm{N}$, and extractable organic carbon (EOC). 
Furthermore, a large phytochemical diversity of low molecular weight polar and nonpolar metabolites among tubers of 29 potato cultivars was reported (Dobson et al. 2008), which could modulate potato defense responses or modulate growth of pathogenic Streptomyces spp.

Dynamics of pathogenic Streptomyces spp. over time. In this study, abundance of pathogenic Streptomyces spp. in SCP and RS was increased at the end of potato growing season. The abundances of pathogenic Streptomyces spp. were greater in Agria, Green Mountain, and Hindenburg in late August 2013 compared with other sampling times. Similarly, Wang and Lazarovits (2005) showed that, in soils planted with scabby tubers, cultivable pathogenic Streptomyces spp. were below $10^{3} \mathrm{CFU} \mathrm{g} \mathrm{g}^{-1}$ of soil in RS at 39 and 57 days after planting but increased to $2.1 \times 10^{5} \mathrm{CFU} \mathrm{g}{ }^{-1}$ of soil at 93 days after planting. In another pathogen-potato system, Phytophthora infestans abundance was greater at the flowering stage in the rhizosphere of three potato cultivars compared with early leaf development stage in greenhouse and field experiments (Gschwendtner et al. 2010). Changes in root exudates over the developmental stage of the potato plants may affect the abundance of pathogenic Streptomyces spp. directly, or may the pathogen indirectly by changing the abundance and diversity of microbial communities at different plant developmental stages. Several studies showed that age-dependent alterations in root exudates shape the rhizosphere microbial communities in potato (Hannula et al. 2012; İnceoğlu et al. 2010, 2011, 2013; Rasche et al. 2006; Van Overbeek and van Elsas 2008; Weinert et al. 2009). Alternatively, the changing environmental conditions (temperature, soil moisture, oxygen level) and soil edaphic properties (EOC, inorganic nitrogen concentrations, $\mathrm{pH}$ ) over the growing season could result in changes in abundance of pathogenic Streptomyces spp. This is supported by the dbRDA analysis results showing that a significant proportion of the variability in pathogenic Streptomyces spp. abundance in SCP over time was explained by VWC in 2013, and by soil temperature in 2014 . Interestingly soil $\mathrm{pH}$, which is a major factor affecting growth of most pathogenic Streptomyces spp. (Loria et al. 1997), explained a small proportion of the variability in the pathogen abundance in SCP and RS in both years.

Correlations between abundance of pathogenic Streptomyces spp. and common scab severity. There were no significant correlations between the abundance of pathogenic Streptomyces spp. and disease severity in any locations for Goldrush and Hindenburg cultivars in 2013 and in 2014, probably due to the presence of abundant pathogenic Streptomyces spp. being supported by the cultivars but without the development of disease symptoms. There was a significant positive correlation between pathogenic Streptomyces spp. abundance in SCP and disease severity for Agria in 2013 and for Green Mountain in SCP and RS in 2014. Pathogenic Streptomyces spp. abundance in soil was reported to be positively correlated with common scab severity (Keinath and Loria 1991), but in some cases, no significant correlations were observed (Keinath and Loria 1991; Qu et al. 2008; Ryan and Kinkel 1997). The absence of significant correlations between the severity of common scab and the abundance of Streptomyces spp. in susceptible cultivars could be explained by the complex interactions between the plant, the pathogen, soil microbial communities and environmental conditions. For example, factors that were reported to influence common scab disease severity included environmental conditions, cultivar susceptibility, soil microbial community diversity and structure, and the aggressiveness of the infecting species (Bouchek-Mechiche et al. 2000; Braun et al. 2017; Loria et al. 1997; Merz et al. 2012; Rosenzweig et al. 2012; Van Overbeek and van Elsas 2008).

In summary, the present study showed that potato cultivars influenced the abundance of pathogenic Streptomyces spp. population in different soil locations during potato growth. It is possible that some cultivars, like Green Mountain, encourage pathogen establishment and growth and/or expression of bacterial pathogenesis. Other cultivars, where abundances of Streptomyces spp. were lower, may inhibit growth of pathogenic Streptomyces spp. or may provide a more favorable habitat for microbial soil communities that outcompete pathogenic Streptomyces spp. Important quantities of potato roots are left to decompose after harvest, and thus cultivars that support greater populations of pathogenic Streptomyces spp. in the RS may increase the load of pathogen inoculum that remains in agricultural fields at the end of a potato growing season.

\section{ACKNOWLEDGMENTS}

We thank C. Clark, S. Whitney, K. Terry, and K. Forward for invaluable help in planting and harvesting the fields and soil sample collection and analysis.

\section{LITERATURE CITED}

An, M., Zhou, X., Wu, F., Ma, Y., and Yang, P. 2011. Rhizosphere soil microorganism populations and community structures of different watermelon cultivars with differing resistance to Fusarium oxysporum f. sp. niveum. Can. J. Microbiol. 57:355-365.

Anderson, M. J. 2001. A new method for non-parametric multivariate analysis of variance. Austral Ecol. 26:32-46.

Arseneault, T., Goyer, C., and Filion, M. 2015. Pseudomonas fluorescens LBUM223 increases potato yield and reduces common scab symptoms in the field. Phytopathology 105:1311-1317.

Balendres, M. A., Nichols, D. S., Tegg, R. S., and Wilson, C. R. 2016. Metabolomes of potato root exudates: Compounds that stimulate resting spore germination of the soil-borne pathogen spongospora subterranea. J. Agric. Food Chem. 64:7466-7474.

Berg, G., and Smalla, K. 2009. Plant species and soil type cooperatively shape the structure and function of microbial communities in the rhizosphere. FEMS Microbiol. Ecol. 68:1-13.

Bernard, G., Asiedu, S. K., and Boswall, P. (eds.). 1993. Atlantic Canada potato guide. Advisory Committee on Potatoes, Canada.

Bignell, D. R. D., Fyans, J. K., and Cheng, Z. 2014. Phytotoxins produced by plant pathogenic Streptomyces species. J. Appl. Microbiol. 116: 223-235.

Bouchek-Mechiche, K., Pasco, C., Andrivon, D., and Jouan, B. 2000. Differences in host range, pathogenicity to potato cultivars and response to soil temperature among Streptomyces species causing common and netted scab in France. Plant Pathol. 49:3-10.

Braun, S. R., Endelman, J. B., Haynes, K. G., and Jansky, S. H. 2017. Quantitative trait loci for resistance to common scab and cold-induced sweetening in diploid potato. Plant Genome 10:1-9.

Clarke, K. R., and Gorley, R. N. 2006. Primer v6: User Manual/Tutorial. Primer-E, Plymouth.

Conn, K. L., and Lazarovits, G. 1998. Impact of animal manures on Verticillium wilt, potato scab, and soil microbial populations. Can. J. Plant Pathol. 21:81-92.

Curless, M. A., Kelling, K. A., Speth, P. E., Stevenson, W. R., and James, R. V. 2012. Effect of manure application timing on potato yield, quality, and disease incidence. Am. J. Potato Res. 89:363-373.

Dijst, G. 1990. Effect of volatile and unstable exudates from underground potato plant parts on sclerotium formation by Rhizoctonia solani AG-3 before and after haulm destruction. Neth. J. Plant Pathol. 96:155-170.

Dobson, G., Shepherd, T., Verrall, S. R., Conner, D., Mcnicol, J. W., Ramsay, G., Shepherd, L. V., Davies, H. V., and Stewart, D. 2008. Phytochemical diversity in tubers of potato cultivars and landraces using a GC-MS metabolomics approach. J. Agric. Food Chem. 56:280-291.

Garbeva, P., van Veen, J. A., and van Elsas, J. D. 2004. Microbial diversity in soil: Selection microbial populations by plant and soil type and implications for disease suppressiveness. Annu. Rev. Phytopathol. 42:243-270.

Gschwendtner, S., Esperschutz, J., Buegger, F., Reichmann, M., Muller, M., Munch, J. C., and Schloter, M. 2011. Effects of genetically modified starch metabolism in potato plants on photosynthate fluxes into the rhizosphere and on microbial degraders of root exudates. FEMS Microbiol. Ecol. 76:564-575.

Gschwendtner, S., Reichmann, M., Müller, M., Radl, V., Munch, J. C., and Schloter, M. 2010. Effects of genetically modified amylopectin-accumulating potato plants on the abundance of beneficial and pathogenic microorganisms in the rhizosphere. Plant Soil 335:413-422.

Hall, T. 2001. BioEdit version 5.0.6. Department of Microbiology. North Carolina State University.

Hannula, S. E., de Boer, W., and van Veen, J. 2012. A 3-year study reveals that plant growth stage, season and field site affect soil fungal communities while cultivar and GM-trait have minor effects. PLoS One 7:e33819.

Hannula, S. E., de Boer, W., and van Veen, J. A. 2010. In situ dynamics of soil fungal communities under different genotypes of potato, including a genetically modified cultivar. Soil Biol. Biochem. 42:2211-2223. 
Haynes, K. G., Wanner, L. A., Thill, C. A., Bradeen, J. M., Miller, J., Novy, R. G., Whitworth, J. L., Corsini, D. L., and Vinyard, B. T. 2010. Common scab trials of potato varieties and advanced selections at three U.S. locations. Am. J. Potato Res. 87:261-276.

Healy, F. G., Krasnoff, S. B., Wach, M., Gibson, D., and Loria, R. 2002. Involvement of cytochrome P450 monooxygenase in thaxtomin A biosynthesis by Streptomyces acidiscabies. J. Bacteriol. 184:2019-2029.

Healy, F. G., Wach, M., Krasnoff, S. B., Gibson, D. M., and Loria, R. 2000. The txtAB genes of the plant pathogen Streptomyces acidiscabies encode a peptide synthetase required for phytotoxin thaxtomin A production and pathogenicity. Mol. Microbiol. 38:794-804.

Hernandez Maldonado, M. L., Falloon, R. E., Butler, R. C., Conner, A. J., and Bulman, S. R. 2013. Spongospora subterranea root infection assessed in two potato cultivars differing in susceptibility to tuber powdery scab. Plant Pathol. 62:1089-1096.

İnceoğlu, Ö., Al-Soud, W. A., Salles, J. F., Semenov, A. V., and van Elsas, J. D. 2011. Comparative analysis of bacterial communities in a potato field as determined by pyrosequencing. PLoS One 6:e23321.

Inceoğlu, Ö., Sablayrolles, C., van Elsas, J. D., and Falcão Salles, J. 2013. Shifts in soil bacterial communities associated with the potato rhizosphere in response to aromatic sulfonate amendments. Appl. Soil Ecol. 63:78-87.

Inceoğlu, Ö., Salles, J. F., van Overbeek, L., and van Elsas, J. D. 2010. Effects of plant genotype and growth stage on the betaproteobacterial communities associated with different potato cultivars in two fields. Appl. Environ. Microbiol. 76:3675-3684.

Keinath, A., and Loria, R. 1989. Population dynamics of Streptomyces scabies and other actinomycetes as related to common scab of potato. Phytopathology 79:681-687.

Keinath, A. P., and Loria, R. 1991. Effects of inoculum density and cultivar resistance on common scab of potato and population dynamics of Streptomyces scabies. Am. J. Potato Res. 68:515-524.

Khatri, B. B., Tegg, R. S., Brown, P. H., and Wilson, C. R. 2011. Temporal association of potato tuber development with susceptibility to common scab and Streptomyces scabiei-induced responses in the potato periderm. Plant Pathol. 60:776-786.

King, R., Lawrence, C., Clark, M., and Calhoun, L. 1989. Isolation and characterization of phytotoxins associates with Streptomyces scabies. J. Chem. Soc. Chem. Commun. 849-850.

Kobayashi, A., Kobayashi, Y. O., Someya, N., and Ikeda, S. 2015. Community analysis of root-and tuber-associated bacteria in field-grown potato plants harboring different resistance levels against common scab. Microbes Environ. 30:301-309.

Kroetsch, D., and Wang, C. 2008: Particle size distribution. Pages713-726 in: Soil Sampling and Methods of Analysis, 2nd. M. R. Carter and E. G. Gregorich, eds. CRC Press, Boca Raton, FL.

Legendre, P., and Anderson, M. J. 1999. Distance-based redundancy analysis: Testing multispecies responses in multifactorial ecological experiments. Ecol. Monogr. 69:1-24.

Li, X. G., Zhang, T. L., Wang, X. X., Hua, K., Zhao, L., and Han, Z. M. 2013. The composition of root exudates from two different resistant peanut cultivars and their effects on the growth of soil-borne pathogen. Int. J. Biol. Sci. 9:164-173.

Loria, R. 2001. Common scab. Pages 14-15 in: Compendium of Potato Diseases, 2nd ed. W. R. Stevenson, R. Loria, G. D. Franc, and D. P. Weingartner, eds. American Phytopathological Society, St. Paul, MN.

Loria, R., Bukhalid, R. A., Fry, B. A., and King, R. R. 1997. Plant pathogenicity in the genus Streptomyces. Plant Dis. 81:836-846.

Merz, U., Lees, A. K., Sullivan, L., Schwarzel, R., Hebeisen, T., Kirk, H. G., Bouchek-Mechiche, K., and Hofferbert, H. R. 2012. Powdery scab resistance in Solanum tuberosum: An assessment of cultivar $\times$ environment effect. Plant Pathol. 61:29-36.

Miller, M. N., Zebarth, B. J., Dandie, C. E., Burton, D. L., Goyer, C., and Trevors, J. T. 2008. Crop residue influence on denitrification, $\mathrm{N}_{2} \mathrm{O}$ emissions and denitrifier community abundance in soil. Soil Biol. Biochem. 40:2553-2562.

Piattoni, F., Roberti, R., Servidio, G., and D'Aulerio, A. Z. 2014. Studies on the potential role of root exudates in the interaction between musk melon roots and Fusarium oxysporum f. sp. melonis. J. Plant Dis. Prot. 121:64-70.
Powelson, M. L., Johnson, K. B., and Rowe, R. C. 1993. Management of diseases caused by soil borne pathogens. Pages 149-158 in: Potato Health Management. R. C. Rowe, ed. American Phytopathological Society, St. Paul, MN

Qu, X., Wanner, L. A., and Christ, B. J. 2008. Using the txtAB operon to quantify pathogenic Streptomyces in potato tubers and soil. Phytopathology 98:405-412.

Raaijmakers, J. M., Paulitz, T. C., Steinberg, C., Alabouvette, C., and Moënne-Loccoz, Y. 2009. The rhizosphere: a playground and battlefield for soilborne pathogens and beneficial microorganisms. Plant Soil 321: 341-361.

Rasche, F., Hödl, V., Poll, C., Kandeler, E., Gerzabek, M. H., van Elsas, J. D., and Sessitsch, A. 2006. Rhizosphere bacteria affected by transgenic potatoes with antibacterial activities compared with the effects of soil, wild-type potatoes, vegetation stage and pathogen exposure. FEMS Microbiol. Ecol. 56:219-235.

Rees, H. W., and Fahmy, S. H. 1984:Page 84 in: Soils of the Agriculture Canada Research Station, Fredericton, NB. LRRI Research Branch Agriculture Canada, Ottawa, ON.

Rosenzweig, N., James, M. T., John, F., Quensen, I. I. I., Qingxiao, M., and Jianjun, J. H. 2012. Microbial communities associated with potato common scab-suppressive soil determined by pyrosequencing analyses. Plant Dis. 96:718-725.

Ryan, A., and Kinkel, L. 1997. Inoculum density and population dynamics of suppressive and pathogenic Streptomyces strains and their relationship to biological control of potato scab. Biol. Control 10:180-186.

Sagova-Mareckova, M., Omelka, M., and Kopecky, J. 2017. Sequential analysis of soil factors related to common scab of potatoes. FEMS Microbiol. Ecol. 93:fiw201.

Smalla, K., Wieland, G., Buchner, A., Zock, A., Parzy, J., Kaiser, S., Roskot, N., Heuer, H., and Berg, G. 2001. Bulk and rhizosphere soil bacterial communities studied by denaturing gradient gel electrophoresis: plantdependent enrichment and seasonal shifts revealed. Appl. Environ. Microbiol. 67:4742-4751.

Soderberg, K. H., Probanza, A., Jumpponen, A., and Baath, E. 2004. The microbial community in the rhizosphere determined by community level physiological profiles(CLPP) and direct soil- and cfu-PLFA techniques. Appl. Soil Ecol. 25:135-145.

St-Onge, R., Gadkar, V. J., Arseneault, T., Goyer, C., and Filion, M. 2011. The ability of Pseudomonas sp. LBUM 223 to produce phenazine-1-carboxylic acid affects the growth of Streptomyces scabies, the expression of thaxtomin biosynthesis genes and the biological control potential against common scab of potato. FEMS Microbiol. Ecol. 75:173-183.

Sun, J., Peng, M., Wang, Y., Li, W., and Xia, Q. 2013. The effects of different disease-resistant cultivars of banana on rhizosphere microbial communities and enzyme activities. FEMS Microbiol. Ecol. 345:121-126.

Van Overbeek, L., and van Elsas, J. D. 2008. Effects of plant genotype and growth stage on the structure of bacterial communities associated with potato (Solanum tuberosum L.). FEMS Microbiol. Ecol. 64:283296.

Wang, A., and Lazarovits, G. 2005. Role of seed tubers in the spread of plant pathogenic Streptomyces and initiating potato common scab disease. Am. J. Potato Res. 82:221-230.

Wanner, L. A. 2007. High proportions of nonpathogenic Streptomyces are associated with common scab-resistant potato lines and less severe disease. Can. J. Microbiol. 53:1062-1075.

Wanner, L. A. 2009. patchwork of Streptomyces species isolated from potato common scab lesions in North America. Am. J. Potato Res. 86:247-264.

Weinert, N., Meincke, R., Gottwald, C., Heuer, H., Gomes, N. C. M., Schloter, M., Berg, G., and Smalla, K. 2009. Rhizosphere communities of genetically modified zeaxanthin-accumulating potato plants and their parent cultivar differ less than those of different potato cultivars. Appl. Environ. Microbiol. 75:3859-3865.

Weller, D. M., Raaijmakers, J. M., Gardener, B. B. M., and Thomashow, L. S. 2002. Microbial populations responsible for specific soil suppressiveness to plant pathogens. Annu. Rev. Phytopathol. 40:309-348.

Wu, Y., Fang, W., Zhu, S., Jin, K., and Ji, D. 2008. The effects of cotton root exudates on the growth and development of Verticillium dahliae. Front. Agric. China 2:435-440. 